ISSN 0258-7122 (Print), 2408-8293 (Online)

Bangladesh J. Agril. Res. 44(1): 27-42, March 2019

\title{
EFFECT OF PLANT GROWTH REGULATORS ON PLANT REGENERATION OF HYACINTH BEAN (LABLAB PURPUREUS (L.) SWEET) THROUGH NODAL EXPLANTS
}

\author{
M. T. ISLAM ${ }^{1}$, M. S. HAQUE ${ }^{2}$, S. RAHMAN ${ }^{3}$ \\ M. R. MOLLA ${ }^{4}$ AND E. R. J. KELLER ${ }^{5}$
}

\begin{abstract}
Nodal explants of three accessions namely BD-101, BD-122 and BD-8001 of hyacinth bean (Lablab purpureus (L.) Sweet) were cultured for four weeks on MS medium supplemented with different concentrations and combinations of NAA $\left(0,0.1 \mathrm{mgl}^{-1}\right)$ and BAP $\left(0.5,1.0\right.$ and $\left.2.5 \mathrm{mgl}^{-1}\right)$ for plant regeneration. The highest shoot initiation was observed in $0.5 \mathrm{mgl}^{-1} \mathrm{BAP}$ while the lowest shoot initiation was found in $2.5 \mathrm{mgl}^{-1} \mathrm{BAP}$ with $0.1 \mathrm{mgl}^{-1} \mathrm{NAA}$. Earlier shoot initiation was exhibited in $0.5 \mathrm{mgl}^{-1} \mathrm{BAP}$ with $0.1 \mathrm{mgl}^{-1} \mathrm{NAA}$. The highest number of leaflets and higher shoot lengths were observed in MS medium. Comparatively higher number of shoots was found in BAP $\left(0.5-2.5 \mathrm{mgl}^{-1}\right)$. The highest percentage of callus was initiated in medium supplemented with $1.0 \mathrm{mgl}^{-}$ ${ }^{1}$ BAP. Earlier callus initiation and larger callus size were found in combination of BAP (0.5-2.5 mgl- $\left.{ }^{-1}\right)$ with $0.1 \mathrm{mgl}^{-1} \mathrm{NAA}$. BD-122 cultured in MS medium was found superior for shoot regeneration through node culture. Four different concentrations of IBA $\left(0.1-1.5 \mathrm{mgl}^{-1}\right)$ were used for rooting. The highest percentage $\left(86.67 \%\right.$ ) of rooting was found in MS medium containing $0.1 \mathrm{mgl}^{-1}$ IBA at four weeks. Rooting frequency decreased with the increasing concentration of IBA. The accession BD-8001 had $99.60 \%$ rooting in $0.5 \mathrm{mgl}^{-1}$ IBA. The highest number of longest roots was exhibited in $0.1 \mathrm{mgl}^{-1}$ IBA. The regeneration protocol developed from nodal explants has applicability in improvement of hyacinth bean.
\end{abstract}

Keywords: Lablab purpureus, nodal explant, growth regulators, regeneration.

\section{Introduction}

Hyacinth bean is a popular vegetable in Bangladesh and South East Asia. The crop is mainly grown for its young pods and green, immature seeds for vegetable purpose. The dry seeds are used as pulse for human consumption in South and Southeast Asia, and East Africa (Magness et al., 1971; Yawalkar and Ram, 2004). It is used as fodder, hay, silage, green manure and cover crop. Lablab leaves and seeds contain 20-28 \% protein (Schaafhausen, 1963). It is grown on

${ }^{1,3 \& 4}$ Plant Genetic Resources Centre, Bangladesh Agricultural Research Institute (BARI), Joydebpur, Gazipur-1701, Bangladesh, ${ }^{2}$ Department of Biotechnology, Bangladesh Agricultural University (BAU), Mymensingh-2202, Bangladesh, ${ }^{5}$ In Vitro Storage and Cryopreservation, Department of Genebank, Leibniz Institute of Plant Genetics and Crop Plant Research (IPK), OT Gatersleben, Correns Strasse 3, D-06466 Stadt Seeland, Germany. 
approximately 20,212 ha of land in Bangladesh during the winter season, yielding an average of $6.37 \mathrm{t}$ of fresh pods per ha for a total yield of about $1,28,676 \mathrm{t}$ (BBS, 2017). Because of its high adaptability, hyacinth bean may help to overcomes some critical seasonal effects in the vegetable production of Bangladesh. Bangladesh Agricultural Research Institute released seven varieties including one photo-insensitive variety of hyacinth bean. However, new varieties with even wider adaptability in stressed environment and resistance to insects and diseases are needed in near future. Systematic research, such as collection, conservation, morpho-molecular characterization, diversity studies, experiments on in vitro regeneration and utilization of hyacinth bean, has been done at PGRC of BARI (Islam et al., 2002; Islam, 2008, 2012; Islam and Haque, 2009, Islam et al., 2010). At present, PGRC conserves 661 accessions of hyacinth bean in the genebank. The availability of an in vitro regeneration system is a pre-requisite for the application of most biotechnological techniques such as production of synthetic seeds, use of somaclones and transgenic plants. In vitro techniques can be used for obtaining virus free materials, clonal propagation, germplasm collection and conservation. Callus initiation and plantlet regeneration by cotyledon, stem and leaf explants of hyacinth bean were reported earlier (Thiruvengadam and Jayabalan, 2000; Kale, 2005). Plant regeneration from immature embryo was also reported (Islam et al., 2010). However, plant regeneration from nodal explant has not been reported in hyacinth bean. Nodal explants are easily available, inexpensive and easy to culture compared to other explants. Therefore, the present investigation was undertaken to develop a reproducible protocol on plant regeneration using nodal explants of hyacinth bean.

\section{Materials and Methods}

Two experiments were conducted with three accessions viz. BD-101, BD-122 and BD-8001 of hyacinth bean at the In Vitro Conservation Laboratory of PGRC, BARI, Joydebpur Gazipur. The accessions are the landraces and are collected from different regions (districts) viz. Naogoan, Hobiganj and Rangamati in Bangladesh in the first experiment. The edible pod shape is elongate and green in BD-101, flat and light purple in BD-122, and flat and light green in BD-8001. The seed colors of the three accessions are yellow, mosaic and black. Plantlets developed through embryo culture were used as source materials. Four weeks aged plantlets were taken on sterilized Petri dishes. Stem segments with 1-2 nodes having axillary buds were aseptically excised from the apical portion without shoot tip under laminar flow and the nodal segments were used as explants. MS salts with vitamins (Murashige and Skoog, 1962) were supplemented with BAP $\left(0.5,1.0\right.$ and $\left.2.5 \mathrm{mgl}^{-1}\right)$ alone or in combination with NAA $\left(0,0.1\right.$ and $\left.0.5 \mathrm{mgl}^{-1}\right)$ in 7 treatments (Table 1). The $\mathrm{pH}$ of the medium was adjusted to 5.8 before autoclaving and the media were solidified with agar $8 \mathrm{gl}^{-1}$. Ten $\mathrm{ml}$ media was poured in each culture tube $(25 \mathrm{x} 150 \mathrm{~mm})$. The medium was 
autoclaved at $1.06 \mathrm{~kg} / \mathrm{cm}^{-2}$ pressure and $121^{\circ} \mathrm{C}$ for $15 \mathrm{~min}$. The nodal explants were placed vertically on the medium keeping the tips upside and gently pressed into the culture medium. The explants were incubated for four weeks in a culture room at $22 \pm 1{ }^{\circ} \mathrm{C}$ under about 2000 lux light provided by cool-white fluorescent tubes maintaining a 16/8 h alternate light/dark cycle and $60-70 \%$ relative humidity. The culture tubes were checked daily to note the morphogenic development and the data were recorded on eight parameters (Table 1). The experimental set up was a $7 \times 3$ factorial in a completely randomized design with five replications each replication consisting of 10 explants. Data were subjected to ANOVA using the General Linear Model procedure. Significant interactions were analyzed. Mean separations were carried out by DMRT at $1 \%$ using the MSTAT program. The percentage data were subjected to square root transformation method (Steel and Torrie, 1960; Gomez and Gomez, 1984). In the second experiment, in vitro raised shoots were transferred to rooting medium for plantlet formation. Shoots were carefully removed from the culture tubes. Each shoot was cut from the basal end and was transferred to MS medium supplemented with $0.1,0.5,1.0$ or $1.5 \mathrm{mgl}^{-1}$ IBA One shoot was placed on the rooting medium and were incubated for four weeks. The experimental set up was $4 \times 3$ factorial CRD with three replications and each replication consisted of 10 explants. Similar methods were followed as of experiment-1 for data analysis in rooting and plantlets development.

\section{Results and Discussion}

\section{Experiment-1}

Percentage of callus initiation: The highest percentage of callus $(99.60 \%)$ was initiated in $1.0 \mathrm{mgl}^{-1} \mathrm{BAP}$, followed by $98.07 \%$ callus in $2.5 \mathrm{mgl}^{-1} \mathrm{BAP}$ and then $96.65 \%$ callus in $2.5 \mathrm{mgl}^{-1} \mathrm{BAP}$ with $0.1 \mathrm{mgl}^{-1} \mathrm{NAA}$ which were statistically similar. The minimum of $85 \%$ callus was obtained from $0.5 \mathrm{mgl}^{-1} \mathrm{BAP}$ with 0.1 $\mathrm{mgl}^{-1}$ NAA (Table 1). However, growth regulator free MS did not initiate any callus in node culture. BD-122 and BD-101 produced 93.20 to $94.09 \%$ callus, respectively (Table 2). The treatment combination of $2.5 \mathrm{mgl}^{-1} \mathrm{BAP}$ and $0.1 \mathrm{mgl}^{-1}$ NAA with BD-101 produced the maximum callus $(99.96 \%)$. On the other hand, the lowest callus was exhibited in $0.5 \mathrm{mgl}^{-1} \mathrm{BAP}$ and $0.1 \mathrm{mgl}^{-1} \mathrm{NAA}$ with BD$122(80 \%)$ (Table 3). Kale (2004) noted that the hyacinth bean genotype Konkan Wal 1, explant stem and growth regulator combination of $2.5 \mathrm{mgl}^{-1}$ IAA +5.0 $\mathrm{mgl}^{-1} \mathrm{BA}$ recorded maximum callus induction $(91.87 \%)$.

Days to callus initiation: Earlier callus initiation was found in case of $2.5 \mathrm{mgl}^{-1}$ BAP with $0.1 \mathrm{mgl}^{-1} \mathrm{NAA}$ (6.0 days) followed by $1.0 \mathrm{mgl}^{-1}$ BAP with $0.1 \mathrm{mgl}^{-1}$ NAA (6.67 days) which were statistically identical (Table 1). However, the callus initiation was most delayed (11.33 days) at the lowest concentration of BAP used $\left(0.5 \mathrm{mgl}^{-1}\right)$ and followed by $1.0 \mathrm{mgl}^{-1} \mathrm{BAP}$ (10.67 days). BD-101 and BD-122 produced callus in 7.5 to 9.17 days, respectively (Table 2). The treatment 

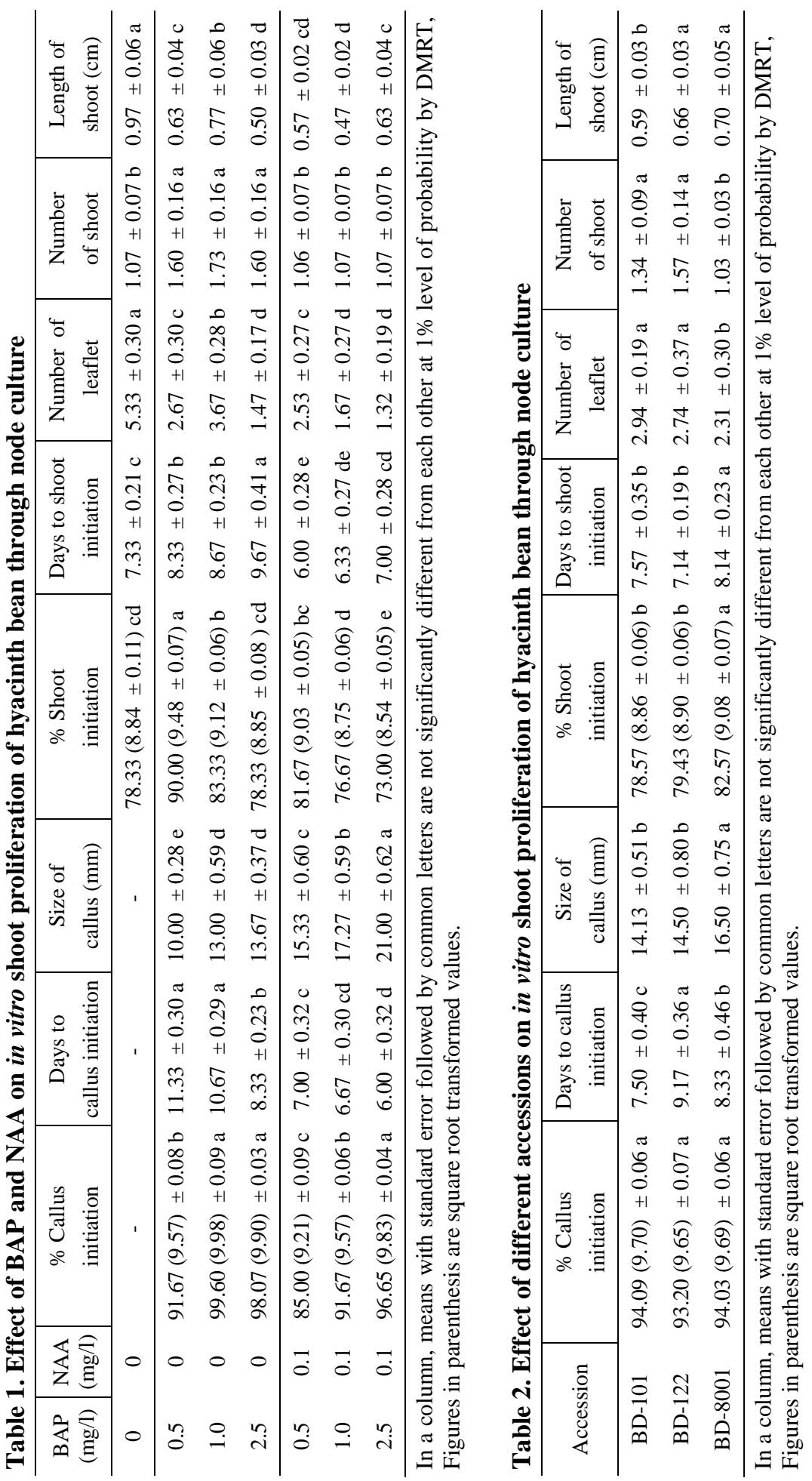


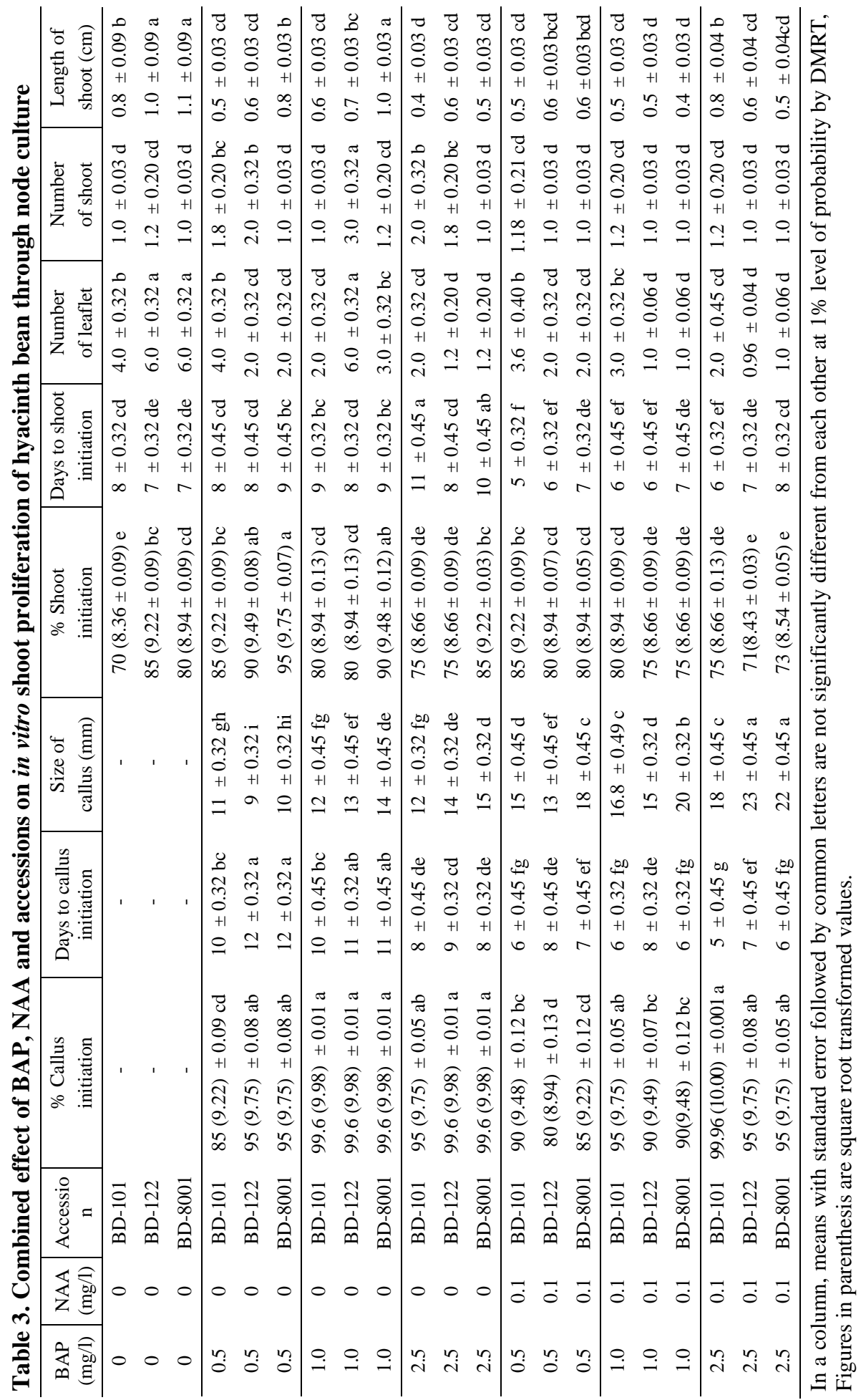



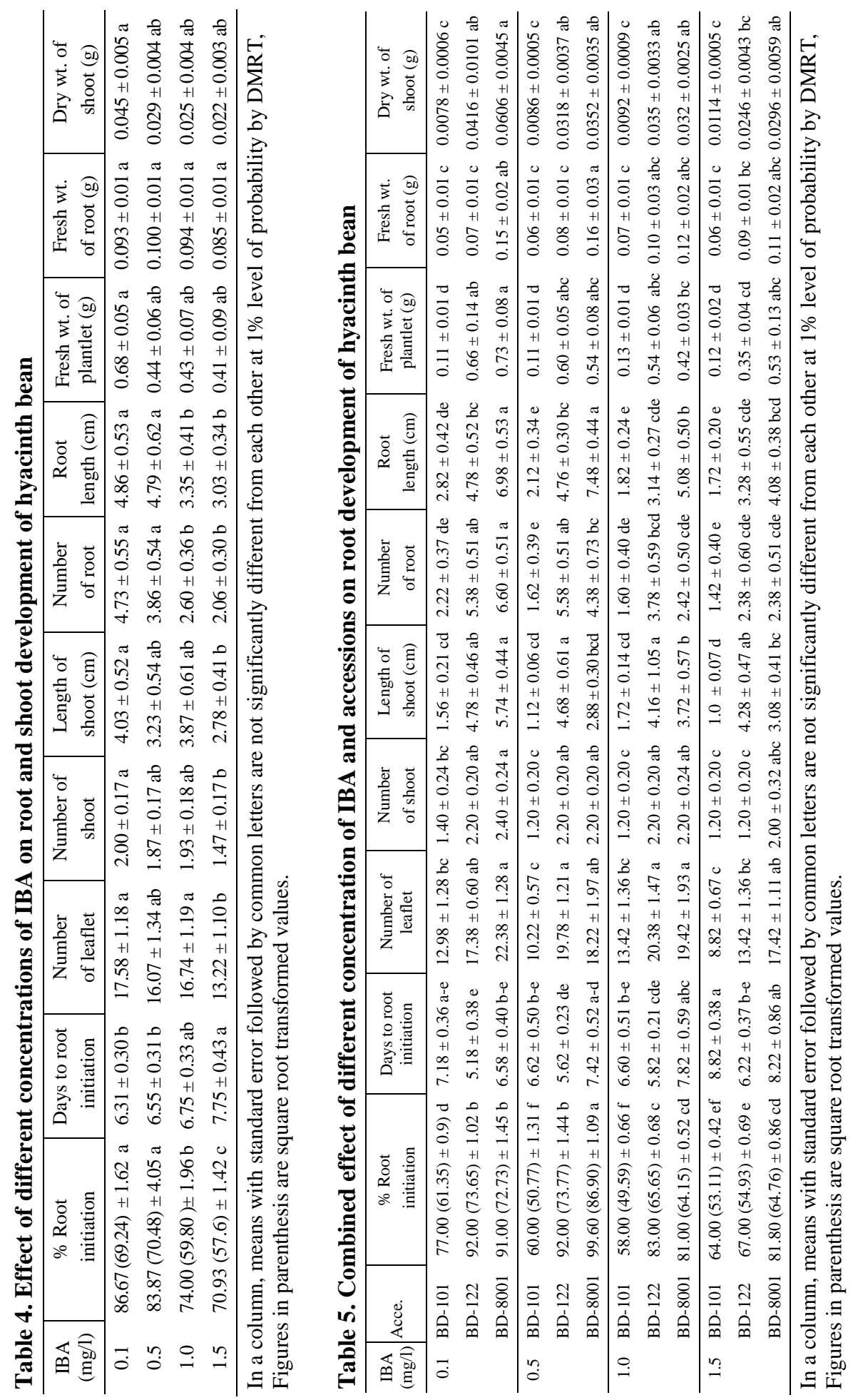
combination of $2.5 \mathrm{mg} / \mathrm{l} \mathrm{BAP}$ and $0.1 \mathrm{mgl}^{-1} \mathrm{NAA}$ with BD-101 took minimum number of days (5 days) for callus initiation. However, it was delayed (12 days) under $0.5 \mathrm{mgl}^{-1}$ BAP with BD-122 or BD-8001 (Table 3). The highest percentage $(95 \%)$ of callus formation was observed in chickpea on MS+3.0 $\mathrm{mgl}^{-1}$ 2,4-D + 3.0 $\mathrm{mgl}^{-1}$ BAP on 8-10 days (Huda et al. , 2003).

Size of callus $(\mathbf{m m})$ : The size of callus varied significantly among the treatments. The largest $(21.00 \mathrm{~mm})$ callus was evident in $2.5 \mathrm{mgl}^{-1}$ BAP with 0.1 $\mathrm{mgl}^{-1}$ NAA. However, the smaller callus $(10.0 \mathrm{~mm})$ was obtained from $0.5 \mathrm{mgl}^{-1}$ BAP (Table 1). BD-8001 produced significantly larger callus $(16.50 \mathrm{~mm})$ and smaller callus $(14.13 \mathrm{~mm}$ ) was found in BD-101 (Table 2). The combined effect of $2.5 \mathrm{mgl}^{-1} \mathrm{BAP}$ and $0.1 \mathrm{mgl}^{-1} \mathrm{NAA}$ with $\mathrm{BD}-122$ produced the largest callus $(23.0 \mathrm{~mm})$ followed by the same combinations with BD-8001 $(22.0 \mathrm{~mm})$. The smallest callus was found in $0.5 \mathrm{mgl}^{-1}$ BAP with BD-122 $(9.0 \mathrm{~mm})$. MS medium without BAP and NAA did not produce any callus from three accessions of hyacinth bean (Table 1, Plate 1).

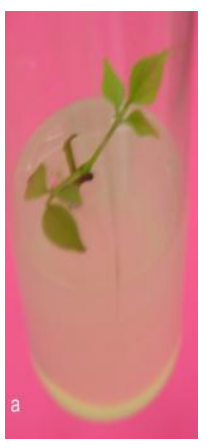

a

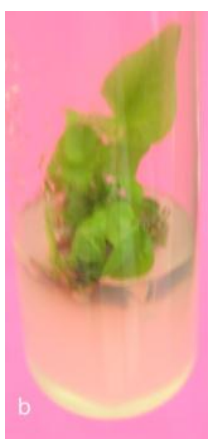

b

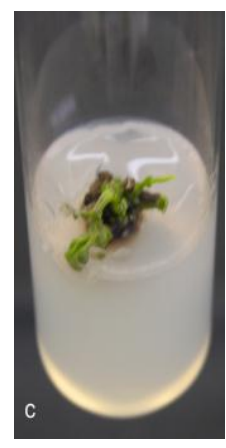

$\mathrm{c}$

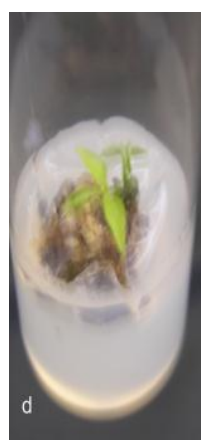

d

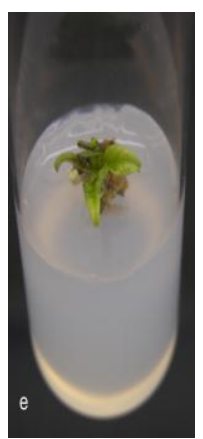

$\mathrm{e}$

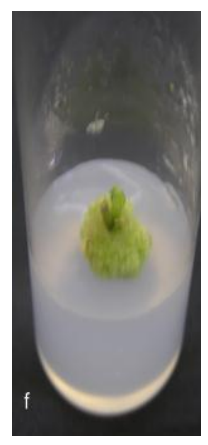

f

Plate 1. Shoot and callus developed from node culture at four weeks of hyacinth bean. The treatments represented by (a) $\mathrm{MS}+\mathrm{BD}-8001$, (b) $\mathrm{MS}+1.0 \mathrm{mgl}^{-1}$ $\mathrm{BAP}+\mathrm{BD}-122$, (c) $\mathrm{MS}+2.5 \mathrm{mgl}^{-1} \mathrm{BAP}+\mathrm{BD}-101$, (d) $\mathrm{MS}+0.5 \mathrm{mgl}^{-1} \mathrm{BAP}$ $+0.1 \mathrm{mgl}^{-1} \mathrm{NAA}+\mathrm{BD}-101$. (e) $\mathrm{MS}+1.0 \mathrm{mgl}^{-1} \mathrm{BAP}+0.1 \mathrm{mgl}^{-1} \mathrm{NAA}+\mathrm{BD}-$ 101. (f) $\mathrm{MS}+2.5 \mathrm{mgl}^{-1} \mathrm{BAP}+0.1 \mathrm{mgl}^{-1} \mathrm{NAA}+\mathrm{BD}-8001$.

Percentage of shoot initiation: The highest percentage (90\%) of shoot initiation was observed in $0.5 \mathrm{mg} / 1 \mathrm{BAP}$ followed by $83.33 \%$ shoots in $1.0 \mathrm{mgl}^{-1} \mathrm{BAP}$ while the lowest $(73 \%)$ was found in $2.5 \mathrm{mgl}^{-1}$ BAP with $0.1 \mathrm{mgl}^{-1}$ NAA (Table1). Among the varieties, BD-8001 exhibited the highest shoot initiation (82.57 \%), however, the lowest was obtained from BD-101 (78.57 \%). BD-122 had $79.43 \%$ shoot regeneration which was statistically identical to BD-101 (Table 2). The combined effect of $0.5 \mathrm{mgl}^{-1} \mathrm{BAP}$ with BD-8001 produced the highest shoot initiation (95\%) followed by $0.5 \mathrm{mgl}^{-1} \mathrm{BAP}$ with BD-122, and 1.0 $\mathrm{mgl}^{-1}$ BAP with BD-8001 (both $90 \%$ ) which were statistically similar (Table 3). The lowest percentage was exhibited in MS (without growth regulators) with BD-101 (70 \%). Tzitzikas et al. (2004) found that $0.55 \mathrm{mgl}^{-1} \mathrm{BAP}$ and $1.1 \mathrm{mgl}^{-1}$ 
BAP in MS exhibited $100 \%$ single shoot regeneration using nodal segment in pea varieties 'Puget' and 'Solara'. Sarker et al. (2003) reported that $0.5 \mathrm{mgl}^{-1}$ BAP, $0.5 \mathrm{mgl}^{-1} \mathrm{Kn}, 0.1 \mathrm{mgl}^{-1} \mathrm{NAA}, 0.1 \mathrm{mgl}^{-1} \mathrm{GA}_{3}$ in MS medium initiated $63 \%$ shoot regeneration while $0.5 \mathrm{mgl}^{-1} \mathrm{BAP}, 0.5 \mathrm{mgl}^{-1} \mathrm{Kn}, 0.1 \mathrm{mgl}^{-1} \mathrm{NAA}, 0.1 \mathrm{mgl}^{-1}$ $\mathrm{GA}_{3}, 5.5 \mathrm{mgl}^{-1}$ tyrosine produced $78 \%$ shoot using nodal segments in lentil.

Days to shoot initiation: Significant variations in development of shoots were observed among the hormonal supplements given to explants. MS medium containing $0.5 \mathrm{mgl}^{-1} \mathrm{BAP}$ and $0.1 \mathrm{mgl}^{-1} \mathrm{NAA}$ took minimum number of days to shoot initiation ( 6 days) followed by $1.0 \mathrm{mgl}^{-1} \mathrm{BAP}$ with $0.1 \mathrm{mgl}^{-1} \mathrm{NAA}(6.33$ days) which were statistically at par (Table 1). On the other hand, $2.5 \mathrm{mgl}^{-1} \mathrm{BAP}$ required the highest number of days (9.67 days). BD-122 took the lowest number of days to shoot initiation (7.14 days) followed by BD-101 (7.57 days) which were statistically identical. The highest number of days was taken by BD-8001 (8.14 days) for shoot initiation (Table 2). The combined effect of $0.5 \mathrm{mgl}^{-1} \mathrm{BAP}$ and $0.1 \mathrm{mgl}^{-1} \mathrm{NAA}$ with BD-101 required the lowest number of days to shoot initiation (5 days) while $2.5 \mathrm{mgl}^{-1} \mathrm{BAP}$ with BD-101 took the highest number of days (11 days) for shoot initiation (Table 3). Sarker and Awal (1999) reported that $0.25 \mathrm{mgl}^{-1} \mathrm{BAP}, 0.1 \mathrm{mgl}^{-1} \mathrm{Kn}$ in MS medium produced shoot at 2-15 days in chickpea 'Binasola' but in the same treatment combination, chickpea 'Hyprosola' produced shoots at 3-15 days using nodal segments.

Number of leaflet: Significantly the highest number of leaflets was found in growth regulator free MS medium (8.27). On the contrary, the lowest number of leaflets was obtained from $2.5 \mathrm{mg} / \mathrm{l}$ BAP with $0.1 \mathrm{mgl}^{-1}$ NAA (1.32) (Table 1). BD-101 and BD-122 produced significantly higher number of leaflets (2.74 to 2.94) than BD-8001 (2.31). The maximum number of leaflets (6) was found from MS with BD-122 and BD-8001, and $1.0 \mathrm{mgl}^{-1} \mathrm{BAP}$ with BD-122. The remaining treatment combinations produced 1.0 to 4.0 leaflets per explant (Table 3; Plate 1).

Number of shoot: BAP ( 0.5 to $\left.2.50 \mathrm{mgl}^{-1}\right)$ produced significantly higher number of shoots (1.60 to 1.73 ) than the remaining treatments (1.06 to 1.07 shoot) (Table 1). The highest number of shoots was exhibited from BD-122 (1.57) followed by BD-101 (1.34). The lowest number of shoots was found in BD-8001 (1.03) (Table 2). The combined effect of $1.0 \mathrm{mgl}^{-1}$ BAP with BD-122 produced significantly higher number of shoots (3.0). The remaining treatments produced significantly lower number of shoots (1.0 to 2.0) (Table 3). Sarker et al. (2003) found that $1.0 \mathrm{mgl}^{-1} \mathrm{BAP}, 0.1 \mathrm{mgl}^{-1} \mathrm{GA}_{3}$ in MS medium produced 1-2 shoots per explant while $0.5 \mathrm{mgl}^{-1} \mathrm{BAP}, 0.5 \mathrm{mgl}^{-1} \mathrm{Kn}, 0.1 \mathrm{mgl}^{-1} \mathrm{NAA}, 0.1 \mathrm{mgl}^{-1}$ GA3, $5.5 \mathrm{mgl}^{-1}$ tyrosine produced 4-5 shoots using nodal segments in lentil regeneration. Combination of $0.25 \mathrm{mgl}^{-1} \mathrm{BAP}, 0.1 \mathrm{mgl}^{-1} \mathrm{Kn}$ in MS produced 7 18 shoots in chickpea 'Binasola' while in the same treatment combination with chickpea 'Hyprosola' produced 6-21 shoots from nodal segments (Sarker and Awal, 1999). 
Length of shoot $(\mathbf{c m})$ : The highest shoot length was found in MS medium (0.97 $\mathrm{cm})$ followed by $1.0 \mathrm{mgl}^{-1} \mathrm{BAP}(0.77 \mathrm{~cm})$ while the lowest was obtained from 1.0 $\mathrm{mgl}^{-1}$ BAP with $1.0 \mathrm{mgl}^{-1}$ NAA $(0.47 \mathrm{~cm})($ Table 1$)$. The accessions produced 0.59 to $0.70 \mathrm{~cm}$ shoot from BD-101 and BD-8001, respectively. (Table 2). MS with BD-8001 and BD-122 produced relatively higher shoot lengths (1.1 and 1.0 $\mathrm{cm}$ ) than the remaining treatments (Plate 1 and Fig. 1). Sarker and Awal (1999) observed that $0.25 \mathrm{mgl}^{-1} \mathrm{BAP}, 0.1 \mathrm{mgl}^{-1} \mathrm{Kn}$ in MS medium produced $2.65 \mathrm{~cm}$ shoot in chickpea 'Binasola' but in the same treatment combination with chickpea 'Hyprosola' produced $2.90 \mathrm{~cm}$ shoot from nodal segments.

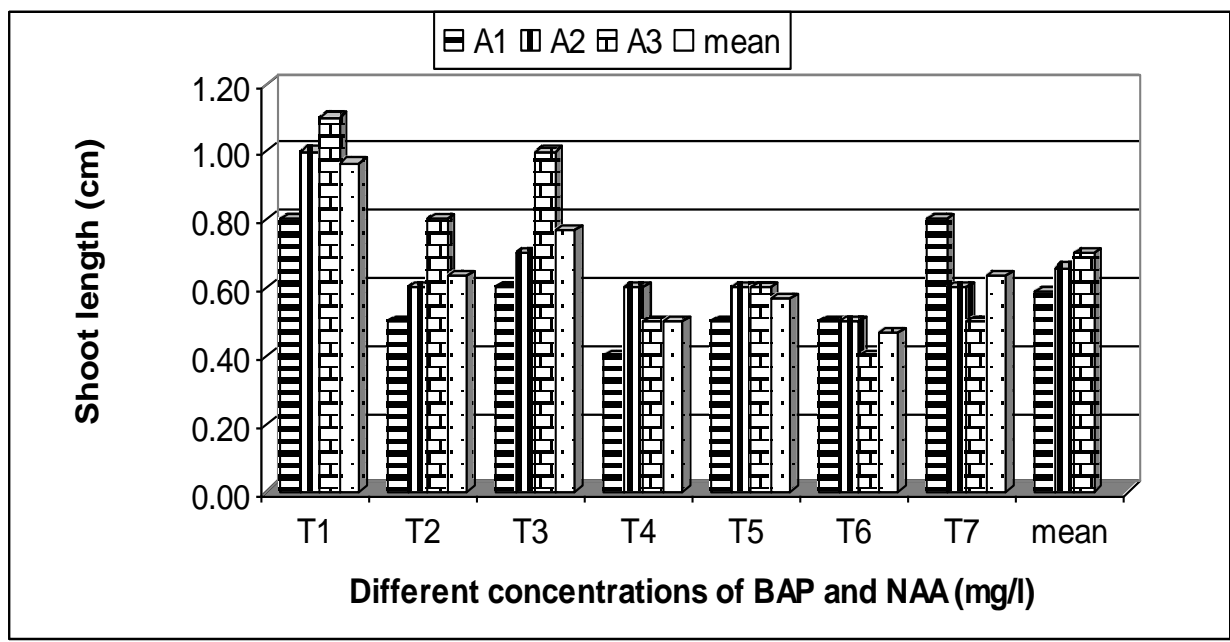

Fig.1. Combined effect of different media composition and accessions on in vitro shoot development in hyacinth bean from node culture. The seven treatments represented by $\mathrm{T}_{1}-\mathrm{MS}$ (control), $\mathrm{T}_{2}-0.5 \mathrm{mgl}^{-1} \mathrm{BAP}, \mathrm{T}_{3}-1.0 \mathrm{mgl}^{-1}$ BAP, T4- $2.5 \mathrm{mgl}^{-1}$ BAP, T5- $0.5 \mathrm{mgl}^{-1}$ BAP + 0.1 $\mathrm{mgl}^{-1} \mathrm{NAA}^{-1}$ 6-1.0 $\mathrm{mgl}^{-1}$ $\mathrm{BAP}+0.1 \mathrm{mgl}^{-1} \mathrm{NAA}, \mathrm{T}_{7-} 2.5 \mathrm{mgl}^{-1} \mathrm{BAP}+0.1 \mathrm{mgl}^{-1} \mathrm{NAA}$, Three accessions represented by A1-BD-101, A2-BD-122 and A3-BD-8001.

The direct regeneration through induction of adventitious shoots using meristematic tissues and complete regeneration other hand became popular as there are no reports of genetic variation in progeny (Maheshwaran and Williams, 1984). Almost all reports of regeneration in legumes have been confined to members of the papilionoidae, the sub family of great economical important plants had been regenerated via organogenesis from 54 different legume species while only 39 species has been shown regeneration from somatic embryos (Parrot, 1992). Recalcitrance of crop is attributed to genetic differences that block the regeneration process in tissue culture. Morphogenic response of many legumes have been shown to be under genetic background (Malik and Saxena, 1992). So in several crops different cultural conditions were found to be necessary for regeneration of different genotypes. Similarly plant regeneration from different tissues is of great importance in obtaining transgenic individual. 
The explants also had highly significant effect on per cent plantlet regeneration. The shoot-tip explant recorded higher regeneration response than cotyledonary node explants in hyacinth bean (Kale, 2004). The regeneration of shoot buds from various explants of pigeon pea such as leaves (Geetha, 1998) has been reported. Similarly, media combination is also greatly influenced on regeneration ability of explants. Naz et al. (2007) reported that the regeneration frequency increased with increase in concentration of cytokinins. Nine genotypes of lablab bean and one popular genotype of dolichos bean $C v$. Konkan bhushan were employed for the regeneration studies. The frequency of shoot formation was influenced by the type of explants. Mature embryo axis with single cotyledon showed maximum frequency of shoot induction followed by mature embryo axis and shoot tip. Cytokinin like BAP was found to be much effective at lower concentration (MS $+0.5 \mathrm{mg} / \mathrm{l} \mathrm{BAP}$ ) and gave $100 \%$ shoot elongation response. But, at high concentration the response to shoot elongation was reduced. Lower level of IAA (MS + 0.5 mg/l BAP) also favoured elongation of shoots (13.33\%) (Kshirsagar et al., 2018). Kale (2004) revealed that shoot tip had grater regeneration potential than cotyledonary explant in field bean. He recorded $92 \%$ regeneration response in Konkan Wal. It indicates that regeneration response depends upon endogenous level of cytokynin in different genotypes. The genotypic variation in shoot induction studies in many pulses confirmed these results. Organogenic differentiation in cell and tissue cultures is due to hormonal manipulation in culture medium. The role of exogenous cytokinin during induction phase is difficult to assess. More commonly used cytokinins are BAP, kinetin, TDZ and Zeantin.

\section{Experiment-2}

Each shoot of experiment-1 was cut from the basal end and was transferred to MS medium supplemented with $0.1,0.5,1.0$ or $1.5 \mathrm{mgl}^{-1}$ IBA in the second experiment.

Percentage of root initiation: Significantly the highest percentage $(86.67 \%)$ of root initiation was observed in MS medium containing $0.1 \mathrm{mgl}^{-1} \mathrm{IBA}$ followed by $83.87 \%$ in $0.5 \mathrm{mgl}^{-1}$ IBA which were statistically similar (Table 4). Rooting frequency decreased with the increase of the IBA concentration. The lowest percentage $(70.93 \%)$ of root initiation was found in $1.5 \mathrm{mgl}^{-1}$ IBA. The combined effect of $0.5 \mathrm{mgl}^{-1} \mathrm{IBA}$ with BD-8001 produced the highest $(99.60 \%)$ frequency of roots followed by $92.00 \%$ in 0.1 to $0.5 \mathrm{mgl}^{-1}$ IBA with BD-122. However, the lowest (58\%) was exhibited in $1.0 \mathrm{mgl}^{-1} \mathrm{IBA}$ with BD-101 (Table 5).Thiruvengadam and Jayabalam (2000) reported that $1.5 \mathrm{mgl}^{-1}$ IBA in MS medium produced $72 \%$ root in callus developed shoot in lablab bean. Huda et al. (2003) found that $1.0 \mathrm{mgl}^{-1} \mathrm{IBA}$ in MS and half MS initiated $66 \%$ and $77 \%$ roots, respectively from callus derived shoot in chickpea. On the other hand, MS medium supplemented with $0.05 \mathrm{mgl}^{-1} \mathrm{IBA}$ was found to be the best in producing roots in chickpea varieties 'Binasola' and 'Hyprosola' (Sarker and Awal, 1999). 
Prem et al. (2003) reported that $4.9 \mu \mathrm{M}$ IBA in half MS medium initiated 90 to $99 \%$ root in guar. Khalafalla and Hattori (2000) found that $0.5 \mathrm{mgl}^{-1}$ IAA in half MS medium initiated $42 \%$ root from in vitro developed shoots in faba bean.

Days to root initiation: The lower number of 6.31 days to root initiation was found in $0.1 \mathrm{mgl}^{-1} \mathrm{IBA}$ followed by 6.55 days in $0.5 \mathrm{mgl}^{-1} \mathrm{BAP}$ and it was increased with the increase of the concentration of IBA (Table 4). The higher number of 7.75 days to root initiation was observed in $1.5 \mathrm{mgl}^{-1}$ IBA. The treatment combination of $0.1 \mathrm{mgl}^{-1}$ IBA with BD-122 took relatively lower number of 5.18 days for shoot initiation. On the contrary, rooting was delayed in case of $1.5 \mathrm{mgl}^{-1} \mathrm{IBA}$ with BD-101 and BD-8001 (8.22 days) (Table 5). Huda et al. (2003) observed that $1.0 \mathrm{mgl}^{-1} \mathrm{IBA}$ in MS and half MS produced roots at 7-12 days and 9-11 days, respectively from callus derived shoots in chickpea. Hoque et al. (2007) found that $0.5 \mathrm{mgl}^{-1} \mathrm{IBA}$ in half strength MS was effective for root induction in mungbean. Tzitzikas et al. (2004) reported that $0.5 \mathrm{mgl}^{-1} \mathrm{IBA}$ in B5 media produced roots after 3 subculturing the plantlet in B5 media containing 1 $\mathrm{mgl}^{-1} \mathrm{GA}_{3}$ in the regeneration of pea. Khalafalla and Hattori (2000) found that 0.5 $\mathrm{mgl}^{-1}$ IAA in half MS produced roots in 12-13 days from in vitro developed shoot in faba bean.

Root length $(\mathbf{c m})$ : The longest $(4.86 \mathrm{~cm})$ roots were found in $0.1 \mathrm{mgl}^{-1} \mathrm{IBA}$ followed by $4.79 \mathrm{~cm}$ root in $0.5 \mathrm{mgl}^{-1}$ IBA which were statistically at par (Table 4). On the contrary, the shortest $3.03 \mathrm{~cm}$ root was obtained from $1.5 \mathrm{mg} / \mathrm{l} \mathrm{IBA}$. The combined effect of $0.5 \mathrm{mgl}^{-1}$ IBA with BD-8001 exhibited the highest 7.48 $\mathrm{cm}$ roots followed by the $6.98 \mathrm{~cm}$ roots in $0.1 \mathrm{mgl}^{-1} \mathrm{IBA}$ with BD-8001. On the other hand, $1.5 \mathrm{mgl}^{-1} \mathrm{IBA}$ with BD-101 exhibited the shortest $1.72 \mathrm{~cm}$ root in hyacinth bean (Plate 2). Huda et al. (2003) reported that $1.0 \mathrm{mgl}^{-1} \mathrm{IBA}$ in MS and half MS produced $5.50 \mathrm{~cm}$ and $5.00 \mathrm{~cm}$ roots, respectively in chickpea. Khalafalla and Hattori (2000) found that $0.5 \mathrm{mgl}^{-1}$ IAA in half MS produced 4.83 $\mathrm{cm}$ longest root in faba bean.

Number of roots: The highest number of 4.73 roots was produced in $0.1 \mathrm{mgl}^{-1}$ IBA followed by 3.86 roots in $0.5 \mathrm{mgl}^{-1}$ IBA which were statistically identical (Table 4). The lowest number of roots was obtained from $1.5 \mathrm{mgl}^{-1} \mathrm{IBA}(2.06)$. The combination of $0.1 \mathrm{mgl}^{-1}$ IBA with BD-8001 produced the highest number of 6.6 roots followed by the same concentration of IBA with BD-122 (5.38) which were statistically identical while the lowest number of 1.42 roots was exhibited in $1.5 \mathrm{mgl}^{-1}$ IBA with BD-101 (Table 5). Huda et al. (2003) observed that $1.0 \mathrm{mgl}^{-1}$ IBA in MS and half MS produced 6.59 and 6.94 roots, respectively in chickpea. Khalafalla and Hattori (2000) noted that $0.5 \mathrm{mgl}^{-1}$ IAA in half MS produced 3.3 roots per explant in faba bean.

Fresh weight of roots (g): MS containing $0.5 \mathrm{mgl}^{-1} \mathrm{IBA}$ noticed the highest 0.10 $\mathrm{g}$ fresh roots while the lowest $0.08 \mathrm{~g}$ fresh roots were obtained from $1.5 \mathrm{mgl}^{-1}$ IBA which were statistically insignificant (Table 4). MS containing $0.5 \mathrm{mgl}^{-1}$ IBA exhibited the highest $0.10 \mathrm{~g}$ fresh roots while the lowest $0.09 \mathrm{~g}$ fresh root 
weight was obtained from $1.5 \mathrm{mgl}^{-1}$ IBA (Table 4). The treatment combination of $0.5 \mathrm{mgl}^{-1} \mathrm{IBA}$ with BD-8001 produced the highest $0.16 \mathrm{~g}$ roots followed by 0.15 $\mathrm{g}$ roots in $0.1 \mathrm{mgl}^{-1} \mathrm{IBA}$ with BD-101 which were statistically at par. On the other hand, the lowest fresh weight $(0.05 \mathrm{~g})$ of roots was found in $0.1 \mathrm{mgl}^{-1} \mathrm{IBA}$ with BD-101 (Table 5).
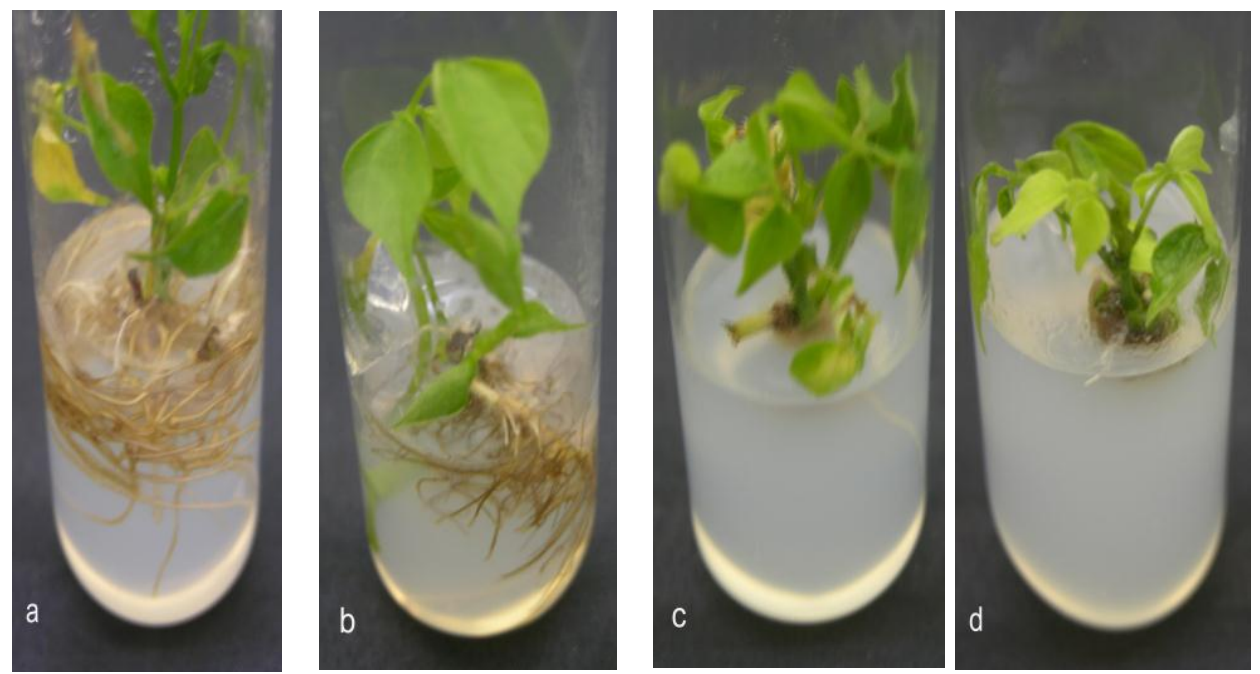

Plate 2. Root developed from shoots of hyacinth bean after four weeks of culture. The treatments are (a) $\mathrm{MS}+0.1 \mathrm{mgl}^{-1} \mathrm{IBA}+\mathrm{BD}-8001$, (b) $\mathrm{MS}+0.5 \mathrm{mgl}^{-1}$ IBA + BD-8001, (c) MS + $1.0 \mathrm{mgl}^{-1} \mathrm{IBA}+\mathrm{BD}-8001$, (d) $\mathrm{MS}+1.5 \mathrm{mgl}^{-1} \mathrm{IBA}^{-1}$ + BD-8001.

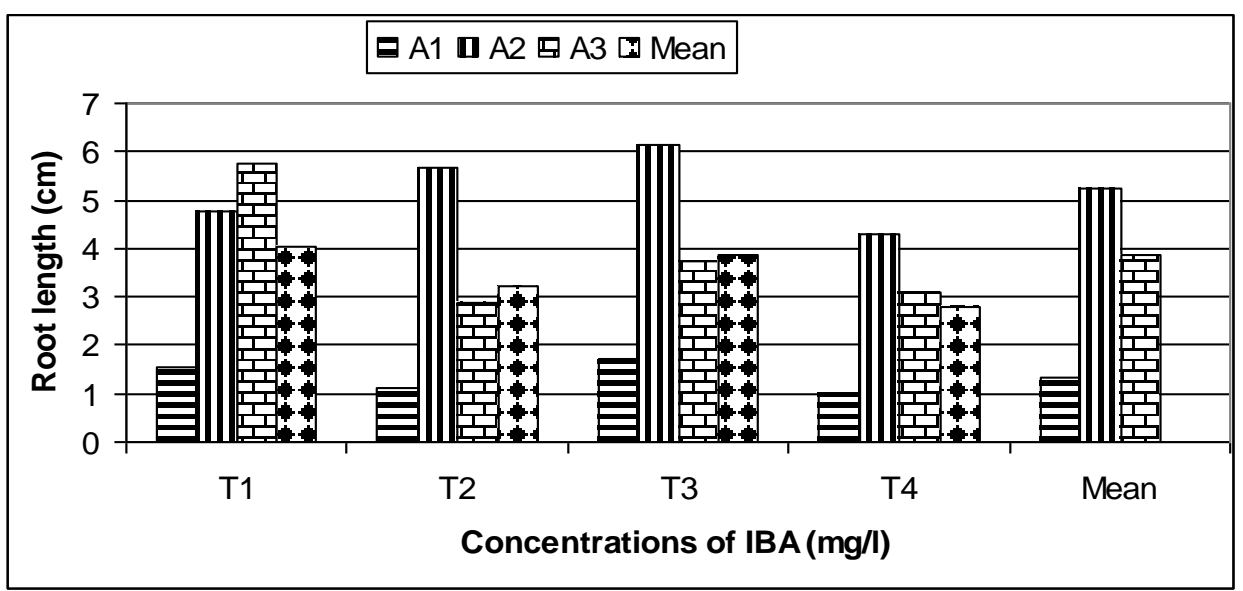

Fig.2 Combined effect of different media and accessions on in vitro development of root length in hyacinth bean from shoot culture at four weeks. The four treatments represented by $T_{1-0.1} \mathrm{mgl}^{-1}$ IBA, $T_{2}-0.5 \mathrm{mgl}^{-1}$ IBA, $T_{3}-1.0 \mathrm{mgl}^{-1}$ IBA and $\mathrm{T}_{4}-1.5 \mathrm{mgl}^{-1}$ IBA in MS. Three accessions represented by A1-BD101, A2-BD-122 and A3-BD-8001. 
Number of leaflet: The highest number of (17.58) leaflets was produced in 0.1 $\mathrm{mgl}^{-1}$ IBA followed by 16.74 leaflets in $0.5 \mathrm{mgl}^{-1}$ IBA (Table 4). On the contrary, the lowest number of (13.22) leaflet was obtained from $1.5 \mathrm{mgl}^{-1} \mathrm{BAP}$.

Number of shoot: The highest number of (2.0) shoots was obtained from 0.1 $\mathrm{mgl}^{-1}$ IBA followed by 1.93 shoots in $1.0 \mathrm{mgl}^{-1} \mathrm{IBA}$ while the minimum 1.47 shoots were produced from $1.5 \mathrm{mgl}^{-1} \mathrm{IBA}$.

Length of shoot $(\mathbf{c m})$ : Further development of shoots during rooting was observed. It was found that the longest $(4.03 \mathrm{~cm})$ shoot was found in $0.1 \mathrm{mgl}^{-1}$ IBA followed by $3.87 \mathrm{~cm}$ and $3.23 \mathrm{~cm}$ shoot from $1.0 \mathrm{mgl}^{-1}$ and $0.5 \mathrm{mgl}^{-1} \mathrm{IBA}$, respectively which were statistically at par. The shortest $(2.78 \mathrm{~cm})$ shoots were produced from $1.5 \mathrm{mgl}^{-1} \mathrm{IBA}$. The highest fresh weight of plantlet $(0.68 \mathrm{~g})$ was produced in $0.1 \mathrm{mgl}^{-1} \mathrm{IBA}$ while the lowest $(0.41 \mathrm{~g})$ was obtained in $1.5 \mathrm{mgl}^{-1}$ IBA.

Fresh weight of plantlet (g): The combined effect of $0.1 \mathrm{mgl}^{-1} \mathrm{IBA}$ with BD8001 produced the highest fresh weight $(0.73 \mathrm{~g})$ of plantlet followed by the 0.66 $\mathrm{g}$ in $0.1 \mathrm{mgl}^{-1} \mathrm{IBA}$ with BD-122. The remaining treatments produced 0.11 to $60 \mathrm{~g}$ fresh weight per plantlet (Table 5).

Dry matter weight $(\mathbf{g})$ : The highest $(0.029 \mathrm{~g})$ dry matter of plantlet was found in $0.1 \mathrm{mgl}^{-1}$ IBA while the lowest dry matter was noted in $1.5 \mathrm{mgl}^{-1}$ IBA (Table 4). The combined effect of $0.1 \mathrm{mgl}^{-1}$ IBA with BD-8001 exhibited the highest $(0.060 \mathrm{~g})$ dry matter production while the lowest was found in $1.0 \mathrm{mgl}^{-1} \mathrm{IBA}$ with BD-101 (Table 5)

As the survivability of plantlets depends mainly on number and type of roots produced from shoots, it was necessary to find out proper auxins and its concentration for inducing roots. Auxins such as IAA, IBA and NAA are most commonly used to induce rooting both in in vitro and ex vitro conditions. In vitro formed roots are obtained which were thin and lack roots hairs. These roots are frequently died or collapsed after the plantlets are removed from culture. There is a need to develop efficient rooting and establishment system, so that the recovery of the maximum in vitro plants will possible. Kshirsagar et al. (2018) reported the highest root induction frequency $(79.51 \%)$ was observed on medium MS+ 1.0 $\mathrm{mg} / \mathrm{l} \mathrm{IBA}+2 \%$ sucrose in hyacinth bean. Comparing capability of IBA, NAA, BAP, maximum number of roots (7.67) were developed in media combination $\mathrm{MS}+1 \mathrm{mg} / \mathrm{l} \mathrm{NAA}+2 \%$ sucrose and MS + $0.5 \mathrm{mg} / \mathrm{l} \mathrm{NAA}$.

\section{Conclusion}

It may be concluded that MS medium without any growth regulators is the superior for shoot proliferation through node culture. Percentages of callus initiation increased with the increase in the concentration of growth regulators. The high concentration of IBA suppressed root development. MS medium containing $0.1 \mathrm{mgl}^{-1} \mathrm{IBA}$ emerged as the superior treatment for rooting of in vitro 
shoots in hyacinth bean. A protocol for in vitro regeneration from nodal explants of hyacinth bean has been developed in this study. This protocol is reproducible for in vitro culture and, short term preservation of hyacinth bean.

\section{References}

BBS. 2017. Bangladesh Bureau of Statistics, Year Book of Agricultural Statistics-2016, Ministry of Planning, Government of the Peoples Republic of Bangladesh, Dhaka. p.306.

Geetha, N., P. Venkatachalam, V. Prakash and G. L.Sita. 1998. High frequency induction of multiple shoots and plant regeneration from seedling explants of pigeon pea (Cajanus cajan L.). Current Sci. 75(10).

Gomez, K. A. and A. A. Gomez. 1984. Statistical Procedures for Agricultural Research. $2^{\text {nd }}$ edition, John Wiley \& Sons, Inc. New York. P. 680.

Hoque, M. I., M. M. Zahan and R. H. Sarker. 2007. In vitro plant regeneration in mungbean (Vigna radiata (L.) Wilczek). Plant Tissue Cult Biotechnol. 17 (2): 209-216.

Huda, S. R., R. Islam, M. A. Bari and M. Asaduzzaman. 2003. Shoot differentiation from cotyledon derived callus of chickpea (Cicer arietinum L.). Plant Tissue Cult. 13 (1): 53-59.

Islam, M. T., M. M. Haque and M. M. Rahman. 2002. Catalogue on hyacinth bean (Dolichus lablab (L.). Plant Genetic Resources Centre, BARI, Gazipur-1701, Bangladesh. p. 55

Islam, M. T. 2008. Morpho-agronomic diversity of hyacinth bean (Lablab purpureus (L.) Sweet). accessions from Bangladesh. Plant Genet Resour Newsl. 156: 72-77 (Italy).

Islam, M. T. and M. M. Haque. 2009. Diversity of hyacinth bean and its conservation and utilization. In: Proc International Conf Plant Breed Seed for Food Security. Bhuiyan, M. S. R. and L. Rahman (eds), Bangladesh Agricultural Research Council (BARC), Farmgate, Dhaka, Bangladesh. 10-12 March 2009. pp. 161-168.

Islam, M. T., M. S. Haque, K. M. Nasiruddin, M. M. Islam and M. M. Haque. 2010. Effects of different media on in vitro regeneration of hyacinth bean (Lablab purpureus (L.) Sweet). In: Role of biotechnology in food security and climate change. Islam, A. S., M. M. Haque, R. H. Sarker and M. I. Haque (eds). Proc Sixth Intl Plant Tissue Cult \& Biotech Conf December 3-5, 2010, Bangladesh Assoc Plant Tissue Cult \& Biotech. Dhaka, Bangladesh. pp. 97-110.

Islam, M. S., M. M. Rahman and T. Hossain. 2010. Physico-morphological variation in hyacinth bean (Lablab purpureus (L.) Sweet). Bangladesh J. Agril. Res. 35 (3): 431-438.

Islam, M. T. 2012. Morpho-molecular characterization, diversity analysis and in vitro regeneration of hyacinth bean (Lablab Purpureus L. Sweet), PhD dissertation, Department of Biotechnology, Bangladesh Agricultural University, Mymensingh. p.195. 
Ismunadji, M. and D. M. Arsyad. 1990. Lablab bean-An unexploited and potential food legume. Training/Workshope on Improvement of Unexploited and Potential Food Legumes in Asia, $27^{\text {th }}$ October to $3^{\text {rd }}$ November 1990, Bogor, Indonesia.

Kale, V. P. 2004. Genotypic differences for callus induction and plantlet regeneration in field bean (Lablab purpureus (L.) Sweet). Indian J. Genet. 64(3):217-220.

Kale, V. P. 2005. Studies on callus initiation and plantlet regeneration in field bean (Lablab purpureus (L.) Sweet. Indian J . Plant Physiol. 10 (1): 60-65.

Khalafalla, M. M. and K. Hattori. 1999. A combination of thidiazuron and benzyladenine promotes multiple shoot production from cotyledonary node explants of faba bean (Vicia faba L.). Plant Growth Regul. 27: 145-148.

Kshirsagar J.K., S.V. Sawardekar, G. B. Sawant, J. P. Devmore and S. M. Jadhav. 2018. In Vitro regeneration study in lablab bean and dolichos bean (Lablab purpureus (L). Sweet) Genotypes. J. Pharmacognosy and Phytochemistry. 7(1): 2782-2789

Magness, J. R., G. M. Markle and C. C. Compton. 1971. Food and Field Crops of the United States, Inter-regional Research Project IR-4, IR Bul. 1 (Bul. 828, New Jersey Agri Exptl. Station). Hyacinth bean. In: Kempanna C., T. K. S.Gowda and M. B. Gowda (eds.), Global Research Digest on Dolichos bean- A Review. Published by Kirkhouse Trust, Oxford, UK.2008. p.19.

Maheshwaran, G. and E. G Williams. 1984. Direct embryoid formation on immature embryos of Trifolium repens, T. pratens and Medicago sativa and rapid clonal propogation of T. repense. Annals of Botany. 54:201-211.

Malik, K. A. and P. K. Saxena. 1992.Thidiazuron induces high- frequency shoot regeneration in intact seedlings of pea (Pisum sativum), Chickpea (Cicer arietinum) and Lentil (Lensculinaris). Aust. J. Plant Physiol.19:731-740.

Murashige, T. and F. Skoog. 1962. A revised medium for rapid growth and bioassays with tobacco tissue cultures. Physiol Plant. 15: 473-497.

Naz, S., A. Ali, F. A. Siddique and J. Iqbal. 2007. Multiple shoot formation from different explants of chickpea (Cicer arietinum L.). Pak. J. Bot. 39(6):2067-2073.

Parrot, W. A., M. A. Bailery, R. E. Ourham and H.V. Mathews. 1992. Tissue culture and regeneration of legumes. In: Moss JP(ed.) Proc. Intworks on Biotechnology and crop improvement in Asia. ICRISAT, Hyderabad, India. pp. 115-148.

Prem D., S. Singh, P. P. Gupta, J. Singh and G. Yadav. 2003. High-frequency multiple shoot regeneration from cotyledonary nodes of guar (Cyamopsis tetragonoloba L. Taub). In Vitro Cell. Dev. Biol. Plant. 39: 384-387.

Sarker, R. H. and S. T. Awal. 1999. In vitro morphogenesis in chickpea (Cicer arietinum L.). Plant Tissue Cult. 9(2): 141-150.

Sarker, R. H., B. M. Mustafa, A. Biswas, S. Mahbub, M. Nahar, R. Hashem and M. I. Hoque. 2003. In vitro regeneration in lentil (Lens culinaris Madik.). Plant Tissue Cult. 13 (2):155-163.

Schaaffhausen, R. V. 1963. Dolichos lablab or hyacinth bean: its uses for feed, food and soil improvement. Economic Botany. 17: 146-153.

Steel, R. G. D. and J. H. Torrie. 1960. Principles and procedures of statistics, McGraw Hill Book Co Inc. New York, USA. p. 481. 
Thiruvengadam, M. and N. Jayabalan. 2000. Regeneration of plantlets from cotyledon explants of Lablab bean (Lablab purpureus (L.). Plant Tissue Cult. 11(1):41-45.

Tzitzikas, E. N., M. Bergervoet, K. Raemarkers, K. P. Vincken, A. Lammeren and R. G. F. Visser. 2004. Regeneration of pea (Pisum sativum L.) by a cyclic organogenic system. Plant Cell Rep. 23: 453-460.

Yawalkar, K. S. and H. H. Ram. 2004. Vegetable Crops of India. Fifth edi. AgriHorticultural Publishing House, Nagpur-440010, India. In: Kempanna C., T. K. S.Gowda and M. B. Gowda (eds.), Global Research Digest on Dolichos bean-A Review. Published by Kirkhouse Trust, Oxford, UK.2008. pp. 235-238. 